\title{
Web-Based Futsal Field Rental Information System Using Laravel Framework
}

\author{
Nurdiansyah \\ Software Engineering Technology, \\ Agricultural Polytechnic of \\ Samarinda, Samarinda, 75131, \\ Indonesia \\ nurdiansyahhh97@gmail.com
}

\author{
Yulianto \\ Software Engineering Technology, \\ Agricultural Polytechnic of \\ Samarinda, Samarinda, 75131, \\ Indonesia \\ yulianto.tile@yahoo.com
}

\author{
Emil Riza Putra* \\ Software Engineering Technology, \\ Agricultural Polytechnic of \\ Samarinda, Samarinda, 75131, \\ Indonesia \\ emilriza92@gmail.com \\ *Corresponding author
}

\begin{abstract}
This research is motivated by Vivo Vive Futsal, which schedules and orders the futsal field offline (having to come directly to the futsal field), this is still less effective and efficient. The purpose of this research is to create a web-based futsal field rental information system in vivo vive futsal. The results of this research are that this information system can solve problems such as providing the scheduling process and online futsal field rental without having to come directly to the futsal field.
\end{abstract}

Keywords - Laravel, PHP, Website, Information System, Futsal.

\section{INTRODUCTION}

The development of information systems using computers is a medium that can make it easier for someone to manage data with the aim of obtaining accurate and easily accessible information by anyone, anywhere, anytime. Good data and information management is very important for the needs of an organization, what other institutions are business-related. One example is the scheduling system in the futsal court rental.

Futsal court rental is a rental business that provides futsal court rental services. In general, the business process at the futsal field rental places still requires customers to come to rent and arrange the desired rental schedule. So that customers do not know the prices and schedules that are still empty directly (Rahma, 2015).

Rentals in each futsal field often encounter problems in their implementation, when there is a futsal rental that has more than one field for rent and the congestion of rental orders from customers causes futsal field staff to have difficulty managing the scheduling of use of the futsal field. The large number of customers who do not get the field because they have been ordered by other customers, so that it causes customers to have difficulty getting the schedule as desired. The customer's need for a different futsal field is one factor that causes the field rental process to be constrained. Not to mention if there is an accumulation of messages from customers, it will certainly make it difficult for field staff to determine which customers should be served first (Anonymous, 2013).

Vivo Five Futsal is a Futsal Field in the East Kalimantan area in the city of Samarinda, engaged in futsal field rental services. Vivo Five Futsal which is located at Jalan Urip Sumoharjo No. 610, Sidomulyo, Samarinda Ilir, Samarinda City, East Kalimantan. Vivo Five Futsal consists of 6 fields which have different sizes and prices. The futsal court rental process at Vivo Five Futsal currently does not have online rental facilities. Based on the description above, there is a need for an online futsal field rental information system to assist companies in providing the best service to customers such as the availability of empty field schedules, then making it easy for customers to get information such as field rental prices, and can do online futsal field orders at Vivo Five Futsal.

The purpose of the author in carrying out this thesis is to optimize the scheduling of use of the futsal field. To present information to customers about the futsal field schedule without having to come in person. To create a feature for members to be able to order futsal courts online.

The expected result of this thesis is the availability of an information system application that can simplify the process of scheduling and leasing an accurate and efficient futsal court.

\section{LITERATURE REVIEW}

Research conducted by (Putra et. al, 2017) entitled Web-Based Design of Information Systems for Rental and Property Sales in Diy. The purpose of this research is to build a web-based information system for rental and property sales in DIY, and to create an application that can display a detailed description of the property to prospective buyers. Based on the results of research, this system can help sellers to market their properties more widely and make it easier for potential buyers to get information about the desired property (Hendini, 2016).

Research conducted by (Ginanjar, 2014) entitled WebBased Car Rental Information Systems in Tour and Travel Services. This methodology uses the Waterfall methodology which consists of the stages of Needs Analysis, System Design, Coding, Program Testing, Maintenance. While the programming language used is PHP programming language and MySQL database is used for its database. Based on the results of the research, this car rental application can accommodate the needs in the activities of rental transactions, reservations, 
payments so that companies can obtain more accurate information from each activity carried out (Subhan, 2012).

Research conducted by (Fitria and Nisa, 2017) entitled Web-Based Online Bus Rental Information System at the Transportation Agency, Barito Kuala Regency. The purpose of this research is to build a bus rental information system so that bus booking and rental transactions can be done online and make it easier for customers to get information on departure schedules, bus availability and information about official services without having to visit the company. The results of this study, apart from making it easier for customers to access information, also improve effectiveness and efficiency, because there is a data management system implemented by administrators.

Research conducted by (Martha et. al, 2013) entitled Design and Manufacture of Web-Based Camera Rental Information Systems and Photo Studio Equipment. The purpose of this research is to get a better image from the customer's point of view, expand the rental network, make it easier to print the necessary reports such as camera rental reports, rented lens reports, rented studio equipment reports, and profit reports from all existing rentals. photo house.

Research conducted by (Hamdani, 2016) entitled Implementation and Testing of Motor Vehicle Rental Service Information Systems Using ISO 9126 Standards Case Study: PT. XYZ. This study aims to create a model of a motorized vehicle rental service information system that is able to help provide optimal service. In this study, the authors used the Object-Oriented Analysis and Design (OOAD) methodology for the development of the proposed system, programming language using Microsoft Visual Net 2008, database software using MySQL and system testing using the ISO 9126 model.

\section{A. Information Systems}

In a broad sense, information systems can be understood as a set of interconnected subsystems, gather together and form one unit, interact and cooperate with one another in certain ways to perform data processing functions, receive input (input ) in the form of data, then process it (processing), and produce output in the form of information as a basis for decision making that is useful and has real value that can be felt as a result both at that time and in the future, supporting operational, managerial activities, and organizational strategy, by utilizing the various available resources available for these functions to achieve goals (Edhy Sutanta, 2011).

\section{B. Definition of rental}

According to Bahtiar (2011) quoted from (Andriyanto, 2019) in his journal, he stated that a lease is an agreement or an agreement where the tenant must pay or provide rewards and benefits to the goods or goods owned by the owner of the loaned goods. Lease laws are permissible or permissible. examples of renting in our daily life, for example, contracting office buildings, house contracts, land leasing for agriculture, vehicle rental / charter, futsal field rental and others.

In a lease there must be goods for rent, the lessor, a reward and an agreement between the owner and the person who rents the goods. The lessee in returning the goods or assets that are rented returns the goods in their entirety as the first time without increasing or increasing unless there is another agreement agreed upon before the goods change hands.

\section{Futsal}

Futsal comes from the Spanish language, namely Footballs and Sala, the combination of the two words means indoor football. According to information sources from FIFA, futsal has been played for the first time in Uruguay and was introduced by Juan Carlos Ceriani, who became a soccer coach from Argentina. In 1930, the game of futsal was first introduced in Uruguay and has spread and attracted attention throughout South America, especially in Brazil. One of the stars of Brazilian football, Pele became interested in developing his futsal talent. Since the development of futsal in Brazil has grown rapidly with the protection of the Federation Internationals de Football Association. Then in 1989, FIFA officially included futsal as a part or sport of football. In 1989 FIFA took over all the management of the futsal world championships (Traynor, 2012).

\section{E. MySQL}

MySQL stands for "My Structured Query Language" is the most favorite database today. This program runs as a server that provides multi-user, accesses a number of databases both multithreaded and multi-user, and has been installed by about 6 million times worldwide. MySQLAB is free, under the GNU General Public License (GPL), but there is also a paid MySQL (Yudhanto dan Prasetyo, 2019).

\section{F. Хатpp}

Xampp is a compilation of favorite free application programs among developers / programmers which is useful for developing websites based on PHP and MySQL. With this one application, we will get a complete software package that can be run on Windows or Linux so that programmers can easily simulate on a local computer before uploading it to the internet. The Xampp software was created and developed by Apache Friends and can be obtained by downloading it at https://www.apachefriends.org/.

This software has advantages, namely it acts as an Apache web server for website development simulations. This web development tool supports popular web technologies such as PHP, MySql, and Perl. Through this program, web programmers can test developed web applications and present them to other parties directly from a computer, without the need to be connected to the internet. Xampp also features PhpMyAdmin database management features like real hosting servers so web development can easily develop database-based web 
applications. Apart from XAMPP there are also LAMP, WAMP, and MAMP (Yudhanto and Prasetyo, 2019).

\section{G. Php MyAdmin}

Php MyAdmin is a web application for managing MySQL databases and MariaDB databases easily through a free interface. This web application is written using the PHP programming language. Like other applications for the web environment (applications that are opened or run using a browser), PhpMyAdmin also supports HTML / XHTML, CSS, and JavaScrip code (Yudhanto and Prasetyo, 2019).

This web application is intended to facilitate the management of Mysql and MariaDB databases by presenting a complete and attractive web interface. The existence of phpMyAdmin which is considered very important and also its open nature makes it one of the applications that are always in cPanel (a popular application for controlling websites). This shows that the web hosting provider puts a lot of trust in phpMyAdmin as one of the web applications that are installed on the server. The advantage of having phpMyAdmin not only can be enjoyed by web hosting providers, we can also install phpMyAdmin on our own server (local server) as long as the minimum requirements have been met.

\section{RESEARCH METHOD}

This research was conducted at Vivo Five Futsal which is located at Jalan Urip Sumoharjo No. 610, Sidomulyo, Samarinda Ilir, Samarinda City, East Kalimantan.

This thesis is carried out for a period of approximately 10 (ten) months. Starting from October 2019 - August 2020.

1. System planning

At this stage the researchers conducted a meeting with the owner of the Vivo Five Futsal Field to identify problems and the objectives of the application or system that will be made. Researchers also collected data by means of interviews and observations.

2. System Analysis Stage

This analysis is used to analyze the company's old system and describe the needs of users in the Vivo Five Futsal Field. At this stage the author will make direct observations or observations of the company's operational activities related to cash orders at the Vivo Five Futsal Field, so that researchers can find out what data or documents are needed in the Information System that will be made later.

\section{System Design}

In the process of designing this system, there are several stages, namely:

a. Use Case Diagram

Where the admin can log in then access the home page, field messages, field names, hours, member prices, nonmember prices, member data, add balances and reports. Members can log in and then access the home page, field messages, and profiles. And guests can only access the home page, field schedule, field prices and social media.

b. Database Modeling
The futsal field rental has a database and there are 9 connected tables, namely the users table, bokings, detail_bokings, prices, jams, fields, daily reports, members, and added_saldos, more details can be seen in Picture 1.

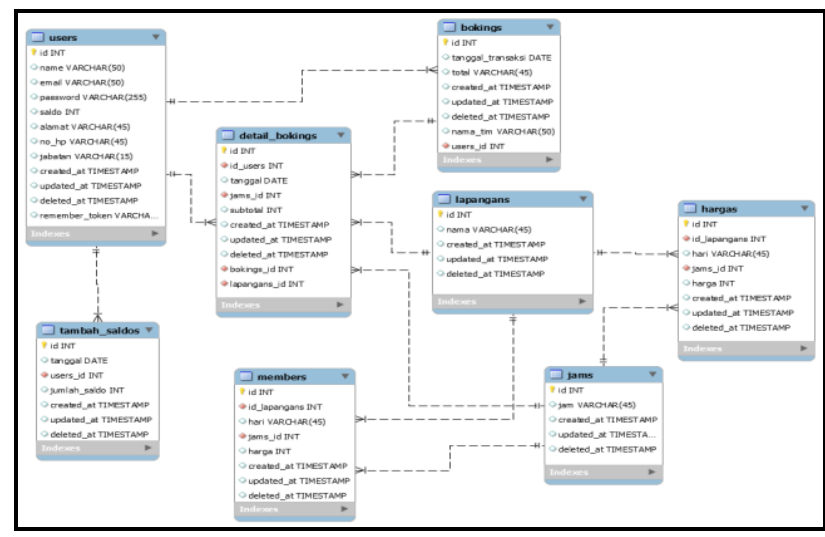

Picture 1. Futsal Court Rental Database

\section{System Testing Stages}

At this stage, it is the stage for testing the application that has been made to check whether there are no more errors or bugs and whether the application is running well according to the desired goal, the test method used is the black box method, which is testing only observing execution results through test data and check the functionality of the software.

\section{RESULTS AND DISCUSSION}

The results of the development of a web-based futsal field rental information system have nine menus for admins, namely home, field message, field, hour, member price, non-member price, member data, add balance, and reports, three menus for members, namely home, field message And the five profiles and menus for guests, namely home, field schedule, field prices, social media and login. The information system was created using the PHP programming language and the laravel 6 framework.

\section{Admin Menu Display}

The following is a display of the results of the information system that has been created:

1) Login page

The login page has several input forms, where the admin must fill in the username and password first before starting the application can be seen in Picture 2. 

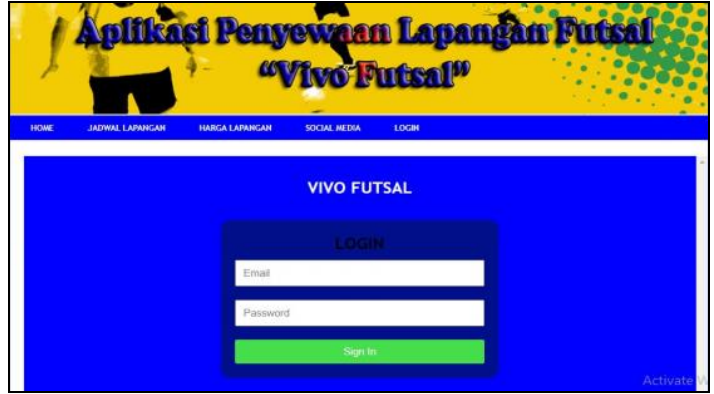

Picture 2. Admin Login Page

2) Home page

The home page is the main display for admin when login is successful, it can be seen in Picture 3.

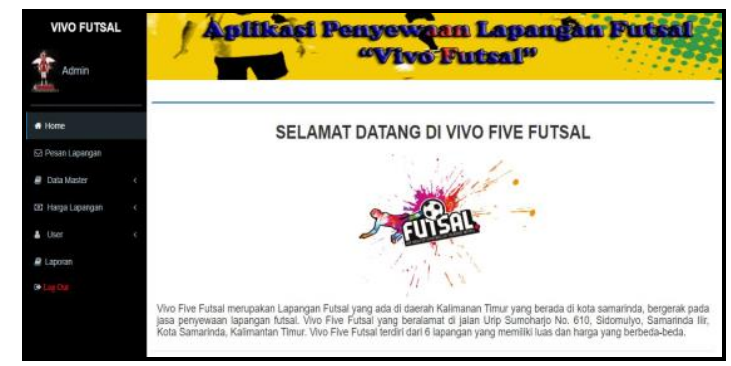

Picture 3. Admin Home Page

3) Order Data page

The order data page displays data that admin has previously input in the field message data. This page has several actions such as field messages, view data, and print data which can be seen in Picture 4.

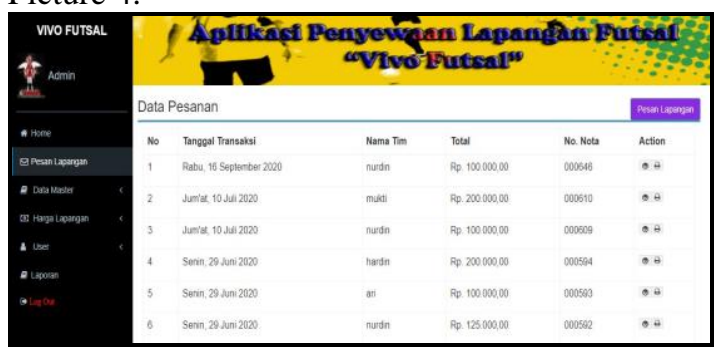

Picture 4. Admin Order Data Page

4) Picture Field Data page

The field data page displays the field name data that admin has previously input. This page has several actions such as adding data, editing data, and deleting data which can be seen in Picture 5 .

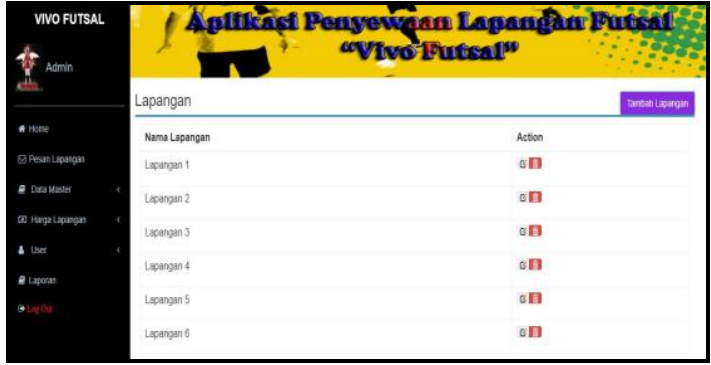

Picture 5. Field Data page

5) Clock Data page

The clock data page displays the clock data that admin has previously input. This page has several actions such as adding data, viewing data, editing data, and deleting data which can be seen in Picture 6.

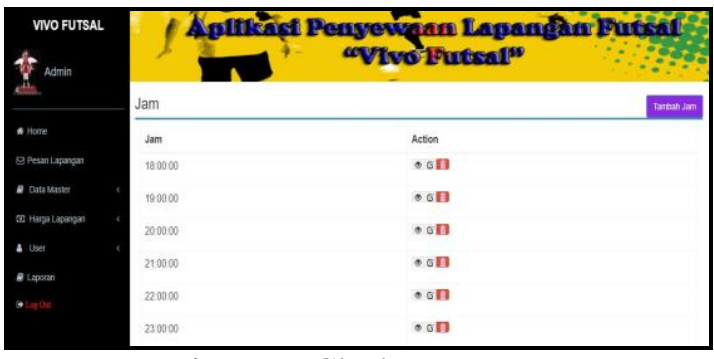

Picture 6. Clock Data page

6) Member Pricing Data page

The member price data page displays field data, days, hours, and prices that admin has previously input. This page has several actions such as adding data, viewing data, editing data, and deleting data which can be seen in Picture 7.

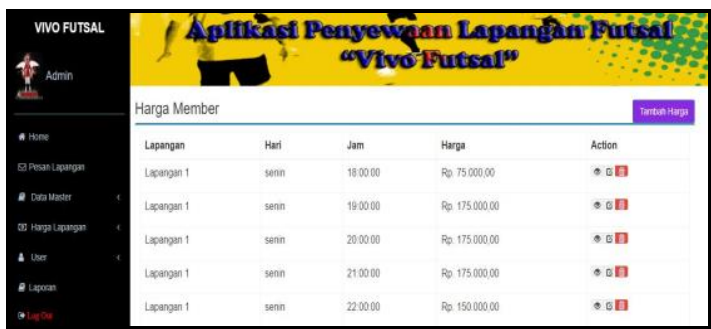

Picture 7. Member Pricing Data page

7) Non Member Pricing Data page

The non-member price data page displays field data, days, hours, and prices that admin has previously input. This page has several actions such as adding data, viewing data, editing data, and deleting data which can be seen in Picture 8 . 


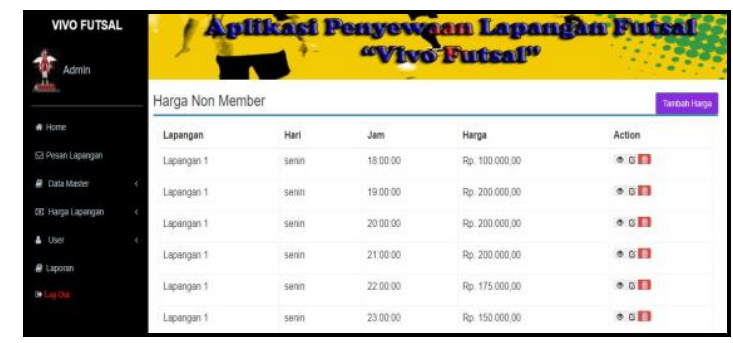

Picture 8. Non Member Pricing Data page

8) Member Data page

The member data page displays data ID, name, email, balance, address, cellphone number, and status that admin has previously input. This page has several actions such as searching data, adding data, viewing data, editing data, and printing data which can be seen in Picture 9.

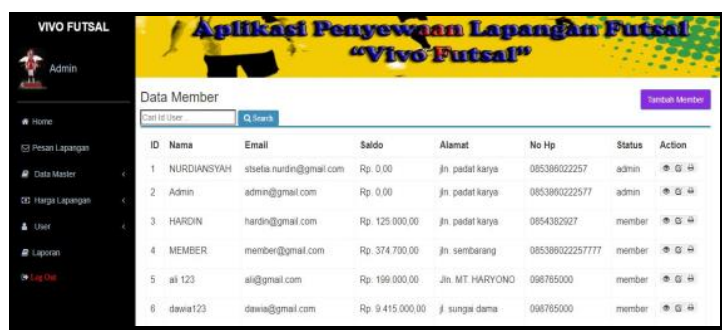

Picture 9. Member Data page

9) Add Balance page

The add balance page displays the date data, member id, member name, and the amount of balance that admin has previously input. This page has actions such as searching data and adding balance which can be seen in Picture 10 .

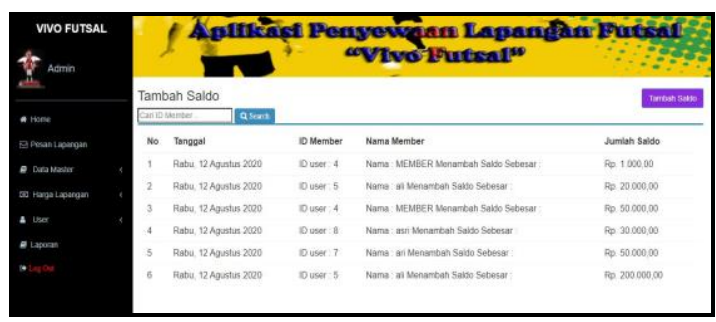

Picture 10. Add Balance page

10) Field Message Report page

The field message report page displays data on the date, monthly and yearly field messages which can be seen in Picture 11.

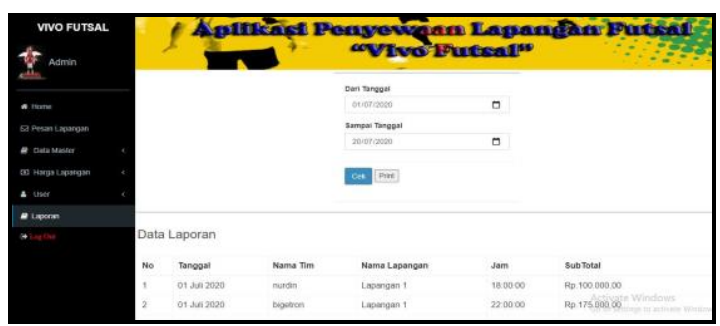

Picture 11. Field Message Report page
2. Member Menu Display

The following is a display of the results of the information system that has been created:

1) Login page

The login page has several input forms, where members must fill in their user name and password first before starting the application, it can be seen in Picture 12 .

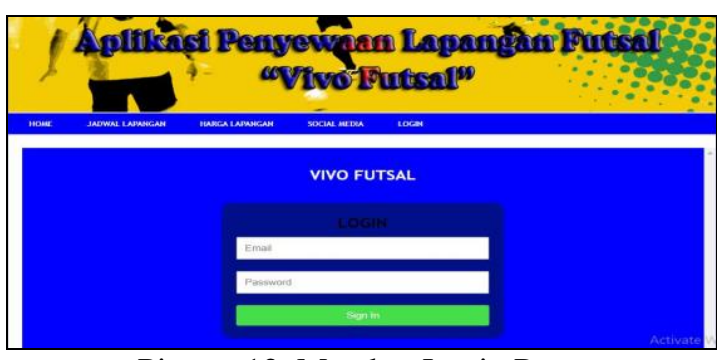

Picture 12. Member Login Page

2) Home page

The home page is the main display for members when they have successfully logged in, it can be seen in Picture 13

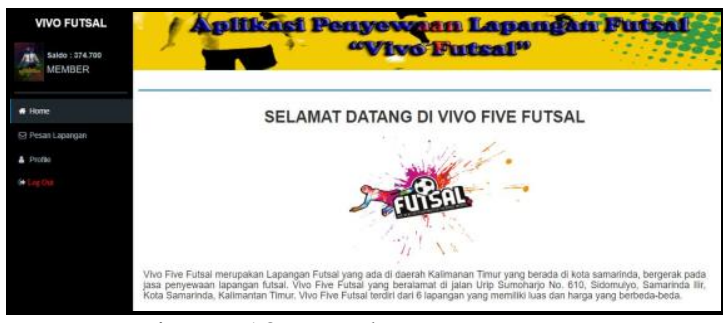

Picture 13. Member Home Page

3) Order Data page

The order data page displays the data that the member has previously input in the field message data. This page has several actions such as field messages, view data, and print data which can be seen in Picture 14

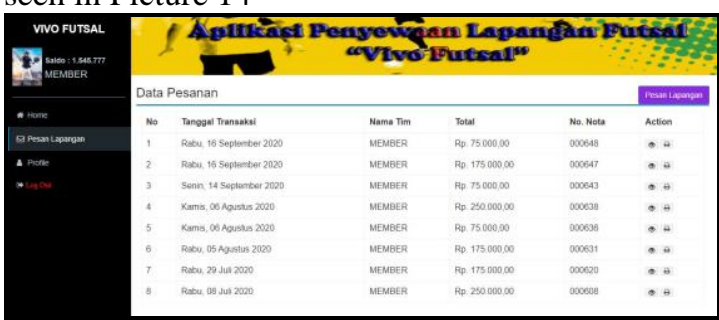

Picture 14. Member Order Data page

4) Profile page

The profile page displays member profile data such as member id, name, email, balance, address, cellphone number, and status. This page has actions such as editing profile and changing password which can be seen in Picture 15 . 


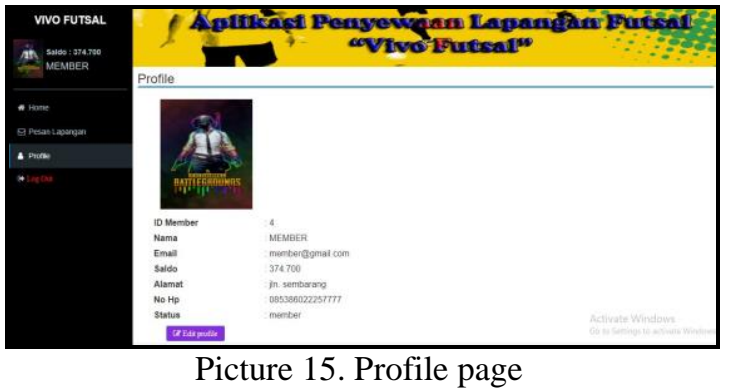

3. Guest Menu Display

The following is a display of the results of the information system that has been created:

1) Home page

The home page is the main display of the futsal court rental application; it can be seen in Picture 16.
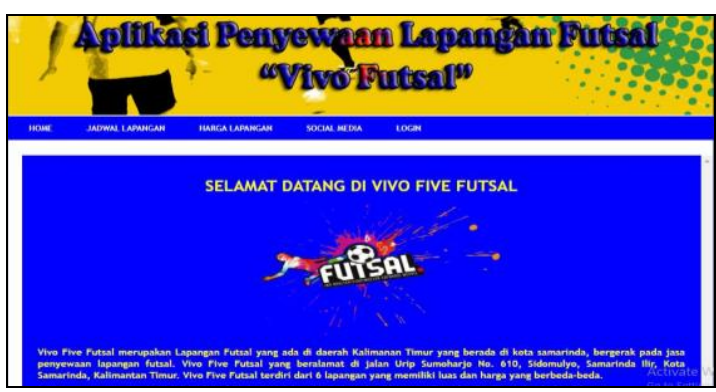

Picture 16. Guest Home Page

2) Field Schedule page

The field schedule page is a display to find out the list of field schedules on Vivo Futsal can be seen in Picture 17.

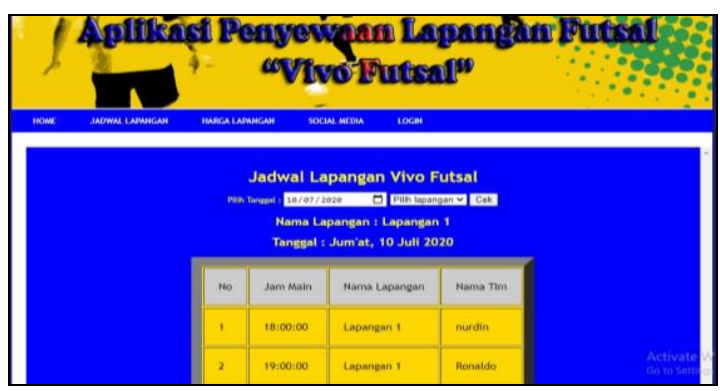

Picture 17. Field Schedule page

3) Field Pricing page

The field price page is a display to find out the field price list on Vivo Futsal can be seen in Picture 18

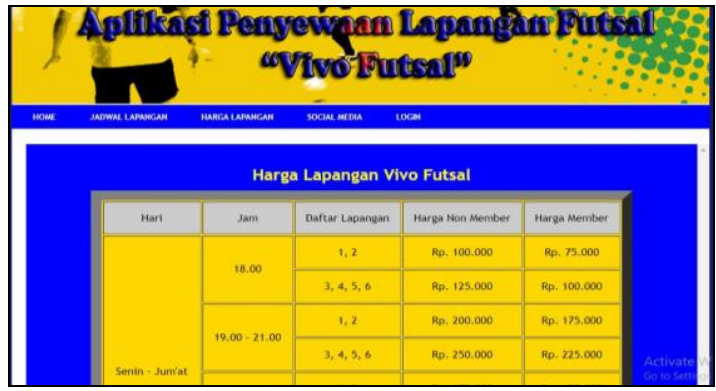

Picture 18. Field Pricing page

4) Social Media Pages

The social media page is a display for viewing social media on Vivo Futsal which can be seen in Picture 19.

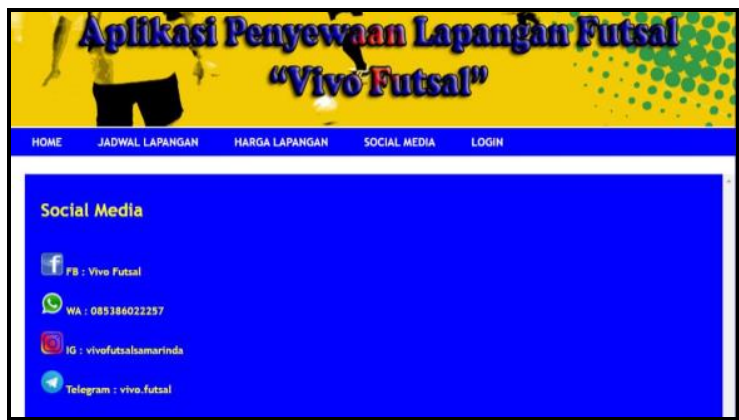

Picture 19. Social Media Pages

5) Login page

The login page is the login display used by the admin or member to enter the futsal field rental application, it can be seen in Picture 20.

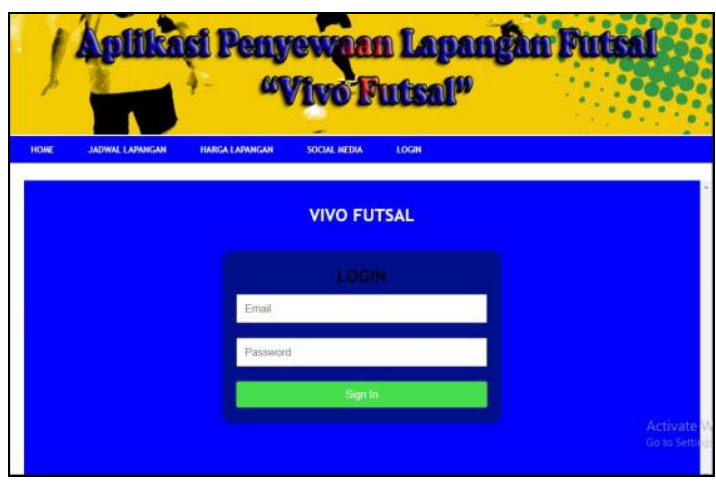

Picture 20. Login Page

Testing the futsal field rental information system application using the black box method. Testing is done by running all existing functions one by one. Then see whether the results of these functions are as expected. The results of the application testers can be seen in Table 1.

Table 1. Black Box Testing

\begin{tabular}{|c|c|c|}
\hline Input & Output & Test results \\
\hline $\begin{array}{c}\text { Click the home } \\
\text { menu }\end{array}$ & $\begin{array}{c}\text { Displays the main } \\
\text { page }\end{array}$ & It works \\
\hline $\begin{array}{c}\text { Click the } \\
\text { Schedule menu }\end{array}$ & $\begin{array}{c}\text { Displays the schedule } \\
\text { page }\end{array}$ & It works \\
\hline $\begin{array}{c}\text { Click the field } \\
\text { price menu }\end{array}$ & $\begin{array}{c}\text { Displays the price field } \\
\text { page }\end{array}$ & \\
\hline
\end{tabular}




\begin{tabular}{|c|c|c|}
\hline $\begin{array}{l}\text { Click the social } \\
\text { media menu }\end{array}$ & $\begin{array}{l}\text { Displays social media } \\
\text { pages }\end{array}$ & It works \\
\hline $\begin{array}{c}\text { Click the login } \\
\text { menu }\end{array}$ & $\begin{array}{l}\text { Displays the login } \\
\text { page }\end{array}$ & It works \\
\hline $\begin{array}{c}\text { Click the } \\
\text { message field } \\
\text { menu }\end{array}$ & $\begin{array}{l}\text { Displays the message } \\
\text { field page }\end{array}$ & It works \\
\hline $\begin{array}{l}\text { Click the field } \\
\text { name menu }\end{array}$ & $\begin{array}{l}\text { Displays the field } \\
\text { name page }\end{array}$ & It works \\
\hline $\begin{array}{l}\text { Click the clock } \\
\text { menu }\end{array}$ & $\begin{array}{l}\text { Displays the clock } \\
\text { page }\end{array}$ & It works \\
\hline $\begin{array}{l}\text { Click the data } \\
\text { member menu }\end{array}$ & $\begin{array}{l}\text { Displays member data } \\
\text { page }\end{array}$ & It works \\
\hline $\begin{array}{l}\text { Click the add } \\
\text { balance menu }\end{array}$ & $\begin{array}{l}\text { Displays the add } \\
\text { balance page }\end{array}$ & It works \\
\hline $\begin{array}{c}\text { Click the report } \\
\text { menu }\end{array}$ & $\begin{array}{l}\text { Displays the report } \\
\text { page }\end{array}$ & It works \\
\hline $\begin{array}{l}\text { Click the edit } \\
\text { button }\end{array}$ & Displays the edit page & It works \\
\hline $\begin{array}{l}\text { Click the delete } \\
\text { button }\end{array}$ & Can delete data & It works \\
\hline $\begin{array}{c}\text { Click the logout } \\
\text { menu }\end{array}$ & Exit application & It works \\
\hline
\end{tabular}

\section{CONCLUSIONS}

Based on the results and discussion previously described as well as the results and analysis of the design and construction of a web-based futsal field rental information system, it can be summarized as follows: This information system can assist the admin in processing the futsal field schedule. This information system can provide information to customers about the futsal field schedule without having to come in person. This information system can help members to order futsal courts online.

Based on the results of making this information system, the authors suggest the following: For the future, this information system can still be developed in line with the development of user requirements specifications. To maintain this data or information system, it is better to back up the data to avoid damage to the system.

\section{REFERENCES}

Andriyanto. (2019). Information System for Futsal Court Rentals on Twins Futsal All Mider Bandar Lampung.

Anonymous. (2013). Futsal Rental. Journal of Chemical Information and Modeling, 53 (9), 1689-1699. https://doi.org/10.1017/CBO9781107415324.004

Fitria and Yulia Nisa. (2017). Web-Based Online Bus Rental Information System. Hasnur Polytechnic Journal of Informatics Engineering, 03, 19-24.

Ginanjar, G. (2014). Web-Based Car Rental Information System at GTS Mobil Bandung. 13 (1999), 10-24.

Hamdani, A. U. (2016). Implementation and Testing of Motor Vehicle Rental Service Information Systems Using ISO 9126 Standards Case Study: PT. XYZ. Journal of Industrial Science and Technology, 13 (2), 218-228. Retrieved from http://ejournal.uinsuska.ac.id/index.php/sitekin/article/view/1441.

Hendini, A. (2016). Uml Modeling Information System Monitoring Sales and Stock of Goods (Case Study: Pontianak Zhezha Distro). IV (2), 107-116.
Martha, A., Priadi, R. A. S., \& Komarudin, M. (2013). Design and Manufacture of Web-Based Camera and Photo Studio Equipment Rental Information Systems. Jitet, 1 (2), 1-10.

Prasetyo, Y. Yudhanto and Helmi Adi. (2019). Easy to Master Laravel Framework. Jakarta: PT Elex Media Komputindo.

Putra, R. P., Riyadi, A., \& Wardani, S. (2017). Design and Build of Web-Based Information Systems for Rental and Property Sales in Diy. NATIONAL SEMINAR of Informatics Dynamics 2017 PGRI University Yogyakarta., 302-311. Retrieved from http://repository.upy.ac.id/id/eprint/1490.

Rahma, N. A. (2015). WEB-based Futsal Field Rental Application and SMS Gateway. E-Proceeding of Applied Science, 1 (1), 663.

Subhan M. 2012. Analysis of System Design. Lentera Ilmu Cendekia: Jakarta.

Sutanta, Edhy, 2011, Database in Conceptual Review. Yogyakarta: Publisher Andi.

Traynor, P. (2012). Chapter 2 literature review and theoretical basis 2.1. (2013), 5-17. 